\title{
30. SEA FLOOR SPREADING HISTORY AND DEEP-SEA DRILLING RESULTS IN THE MADAGASCAR AND MASCARENE BASINS, WESTERN INDIAN OCEAN
}

\author{
R. Schlich, Institut de Physique du Globe de Paris, Saint-Maur-des-Fossés, France
}

\begin{abstract}
Bathymetric and magnetic data collected over 6 years in the Madagascar and Mascarene basins by Gallieni and Marion Dufresne are used in this paper. Several well-established transform faults, nearly parallel to the general northeast-southwest topographic trend of the Southwest Indian Ridge, are traced throughout the Madagascar and Mascarene basins between the Mascarene Plateau and the Madagascar Ridge. Late Cretaceous, Paleocene, and early Eocene magnetic anomalies (33 to 19) related to spreading from the Central Indian Ridge are clearly identified in these basins. Changes in spreading rates and directions are recorded between anomalies 31 and 30 (71 m.y. B.P.), near anomaly 27 (67.5 m.y. B.P.), and just before anomaly 22 (57 m.y. B.P.). The spreading (half) rates are respectively in these intervals: $4.0 \mathrm{~cm} / \mathrm{yr}$ (33 to 31$), 12.2 \mathrm{~cm} / \mathrm{yr}(30$ to 28$), 7.1$ $\mathrm{cm} / \mathrm{yr}(27$ to 23 ), and about $4.0 \mathrm{~cm} / \mathrm{yr}$ (after anomaly 23 ). The magnetic ages, derived from the identified magnetic anomalies, are compared to the biostratigraphic age established by drilling at Site 245 in the Madagascar Basin and Site 239 in the Mascarene Basin. These data show that the present time scale of geomagnetic field reversals remains valid for Late Cretaceous time, but the present scale may be approximately 7 percent too old for Paleogene time. However, it is still necessary to obtain complementary drilling data on identified magnetic anomalies before deriving a new time scale for magnetic reversals.
\end{abstract}

\section{INTRODUCTION}

The Indian Ocean is bounded by the African, Indian, Australian, and Antarctic continents, which were formed after the breakup of Gondwanaland. The reconstruction of this original continent, to which the creation and evolution of the Indian Ocean is related, is difficult by contrast to the world's other major oceans. For instance, in the Atlantic Ocean we are mainly concerned with only two distinct blocks, but here we have a large number of continental fragments separated by a rather complex system of oceanic ridges. Moreover, the existence of several submarine plateaus, sometimes extremely wide and not always capped by islands, are interpreted either as uplifted oceanic crust (Udintsev, 1965; Zhivago, 1967) or as continental fragments (Heezen and Tharp, 1965; Francis and Raitt, 1967; Laughton et al., 1970; Schlich et al., 1971), which makes this reconstruction even more difficult. Within the concepts of sea floor spreading, continental drift, and plate tectonics, it should be possible from studies of the fracture zones and magnetic lineations to trace the movements of these continents and continental fragments and thus the evolution of the Indian Ocean and the structure of its main oceanic basins. The Deep Sea Drilling Project in the Indian Ocean (Leg 22 to Leg 27) has given us the opportunity to check whether the proposed reconstructions are valid or not and will surely guide further investigations.

The purpose of this paper is to sketch the structure of two major oceanic basins in the Southwestern Indian Ocean: the Madagascar Basin and the Mascarene Basin. Strikes of transform faults are mapped, in some detail, in both of these basins, and magnetic lineations are interpreted according to the Vine and Matthews (1963) hypothesis. Since Glomar Challenger (Leg 25) drilled one site in the Madagascar Basin (Site 245) and one site in the Mascarene Basin (Site 239), it is also an attempt to compare the age given by the biostratigraphic information with the oceanic crust age derived from magnetic lineations. It is clear, and has been proven, that the strike of transform faults and magnetic lineations are the most reliable and best tools to study the evolution of oceanic basins.

\section{STRUCTURE OF THE WESTERN INDIAN OCEAN}

North of $20^{\circ} \mathrm{S}$, the Central Indian Ridge is bounded on the east by the Chagos Laccadive Ridge and on the west by the Mascarene Plateau. It broadly follows a north-south line which extends into the southern end of the Carlsberg Ridge at about the equator. Further to the north, the Carlsberg Ridge trends in a southeast-northwest direction, and beyond the Owen Fracture Zone, it is prolonged into the 
Gulf of Aden by the Sheba Ridge. These structures, and the adjacent oceanic basins, have been studied in detail by several authors. Langseth and Taylor (1967) and Fisher et al. (1967, 1968, and 1971) have shown that the Central Indian Ridge is dominated by northeast-southwest trending fracture zones. Fisher et al. (1971) have identified and mapped young magnetic anomalies related to this ridge between the Chagos Laccadive Ridge and the Mascarene Plateau. They found a spreading (half) rate since Miocene time of approximately 1.8 to $2.4 \mathrm{~cm} / \mathrm{yr}$. Cann and Vine (1966), Vine (1966), Le Pichon and Heirtzler (1968), and Fisher et al. (1968) have identified similar magnetic anomalies associated with the Carlsberg Ridge, with spreading (half) rates of about 1.2 to $1.3 \mathrm{~cm} / \mathrm{yr}$. Matthews (1966) and Fisher et al. (1968) observed very characteristic magnetic anomalies of large amplitude and long wave lengths beyond anomaly 5 (10 m.y.) in the Arabian Sea and in the area between Seychelles Islands and the Carlsberg Ridge. In the Arabian Sea, these anomalies trend in an east-west direction, whereas in the northern Somali Basin their strike is west northwest-east southeast. These directions differ notably from the strike of the presently active Carlsberg Ridge. McKenzie and Sclater (1971) have identified these anomalies as anomalies 23 to 29 of the Heirtzler et al. (1968) time scale; they found a spreading (half) rate of $6.5 \mathrm{~cm} / \mathrm{yr}$ for these magnetic sequences on both sides of the Carlsberg Ridge. Considering the distance of anomaly 28 (formed about 68 m.y. ago) from the ridge crest, they concluded that spreading must have been very slow or even stopped between 58 and 10 m.y. ago.

In the Central Indian Ocean, which is bounded on the north by India, on the south by the Southeast Indian Ridge, on the west by the Chagos-Laccadive Ridge, and on the east by the Ninetyeast Ridge, McKenzie and Sclater (1971) identified anomalies 22 to 33 of the Heirtzler et al. (1968) time scale. For these Paleocene and Late Cretaceous anomalies they found a spreading (half) rate of about 8.0 $\mathrm{cm} / \mathrm{yr}$ between anomalies 22 and 30 and about $5.6 \mathrm{~cm} / \mathrm{yr}$ for the older anomalies beyond anomaly 30 . The strike of these anomalies is about $96^{\circ} \mathrm{E}$. Magnetic anomalies younger than 22 (56 m.y.) were not observed at this time by these authors, and they suggested, as for the Arabian Sea and the northern Somali Basin, a slow spreading rate and even a stop of spreading after anomaly 22 . This was somewhat surprising since these young magnetic anomalies, associated with the Southeast Indian Ridge, were mapped by Schlich and Patriat (1971a) in the northern part of the Crozet Basin. Now Sclater and Fisher (in press), Sclater et al. (in press) have recognized these younger anomalies in the southern part of the Central Indian Ocean and found a spreading (half) rate of about $2.5 \mathrm{~cm} / \mathrm{yr}$ between anomalies 16 and 5 .

South of the Mascarene Islands, the Central Indian Ridge splits into two distinct branches which, respectively, separate the Antarctic continent from Australia and from Africa. The Southeast Indian Ridge extends from near the Mascarene Islands through Amsterdam and St. Paul islands and joins the Pacific Antarctic Ridge south of Australia. The Southwest Indian Ridge extends south of the Mascarene Islands, past Marion and Prince Edward islands and is joined by the southern end of the Mid-Atlantic Ridge west of Bouvet Island. Between these two ridges and the bordering continents are several plateaus: towards Africa the Madagascar Ridge, the Mozambique Ridge, and the Agulhas Plateau; and towards Antarctica the Crozet and Kerguelen-Heard plateaus. Between the seismically active mid-ocean ridge systems and these plateaus are several deep oceanic basins: east of Madagascar the Mascarene Basin; to the west, limited by the Mozambique and Madagascar ridges, the Mozambique Basin; to the southeast of Madgascar, the Madagascar Basin; and in the central part of the South Indian Ocean, limited by the Southwest and Southeast Indian ridges, the Crozet Basin.

The Southwest Indian Ridge is a nearly north-south spreading ridge offset by several fracture zones which run almost north-south. The spreading (half) rate along this ridge, essentially computed from the axial magnetic anomalies, is about $0.6 \mathrm{~cm} / \mathrm{yr}$ to $0.9 \mathrm{~cm} / \mathrm{yr}$ (Schlich and Patriat, 1971b; Bergh, 1971). McKenzie and Sclater (1971) computed, by vector addition, the spreading along this ridge taking into account the motion of the Somalian and Antarctic plates relative to India and found similar results. Several long bathymetric and magnetic profiles, run in a north-northwest-south-southeast direction across this ridge, lead to the conclusion that spreading was not initiated prior to 40 or 50 m.y. ago (Schlich, in preparation).

The Southeast Indian Ridge has been a northeastsouthwest spreading ridge for the last 45 million years (Schlich and Patriat, 1967, 1971b). The central anomaly associated with this ridge has been clearly identified and is offset in the vicinity of Amsterdam and St. Paul islands by several fracture zones running in a northeast-southwest direction. The present spreading (half) rate is $3.4 \mathrm{~cm} / \mathrm{yr}$, but Schlich and Patriat (1971a) observed several changes in spreading rate accompanied by minor spreading direction changes at about 10 (anomaly 5), 19 (anomaly 5c), 24 (anomaly 6a), and 45 (anomaly 18) million years. Le Pichon and Heirtzler (1968) and Schlich and Patriat (1971c) recognized anomalies 17 and 18 on both sides of Kerguelen-Heard Plateau. Beyond anomaly 18 , the magnetic pattern can still be identified, but the direction of spreading appears to be more or less northnortheast-south-southwest. In the Crozet and Madagascar basins, Schlich and Patriat (1971c) observed very characteristic magnetic anomalies of large amplitude and long wavelengths which can be correlated between adjacent tracks in a west-northwest-east-southeast direction. These anomalies were identified as anomalies 23 to 27 of the Heirtzler et al. (1968) time scale (Schlich et al., 1972). The large-scale right lateral offset of these anomaly patterns on each side of the Southwest Indian Ridge is about $1000 \mathrm{~km}$ (Figure 1).

\section{DATA AND METHOD USED}

The data used (Figure 2) for this study are bathymetric and magnetic profiles collected in the Southwestern Indian Ocean by Gallieni between 1967 and 1972 (Cruises GA-0 to GA-6), by Glomar Challenger in 1972 (Leg 25), and by Marion Dufresne in 1973 (Cruises MD-1 and MD-2). The bathymetric data have been recorded with an Ocean Sonic GDR-T depth recorder and have been digitized in meters (at 


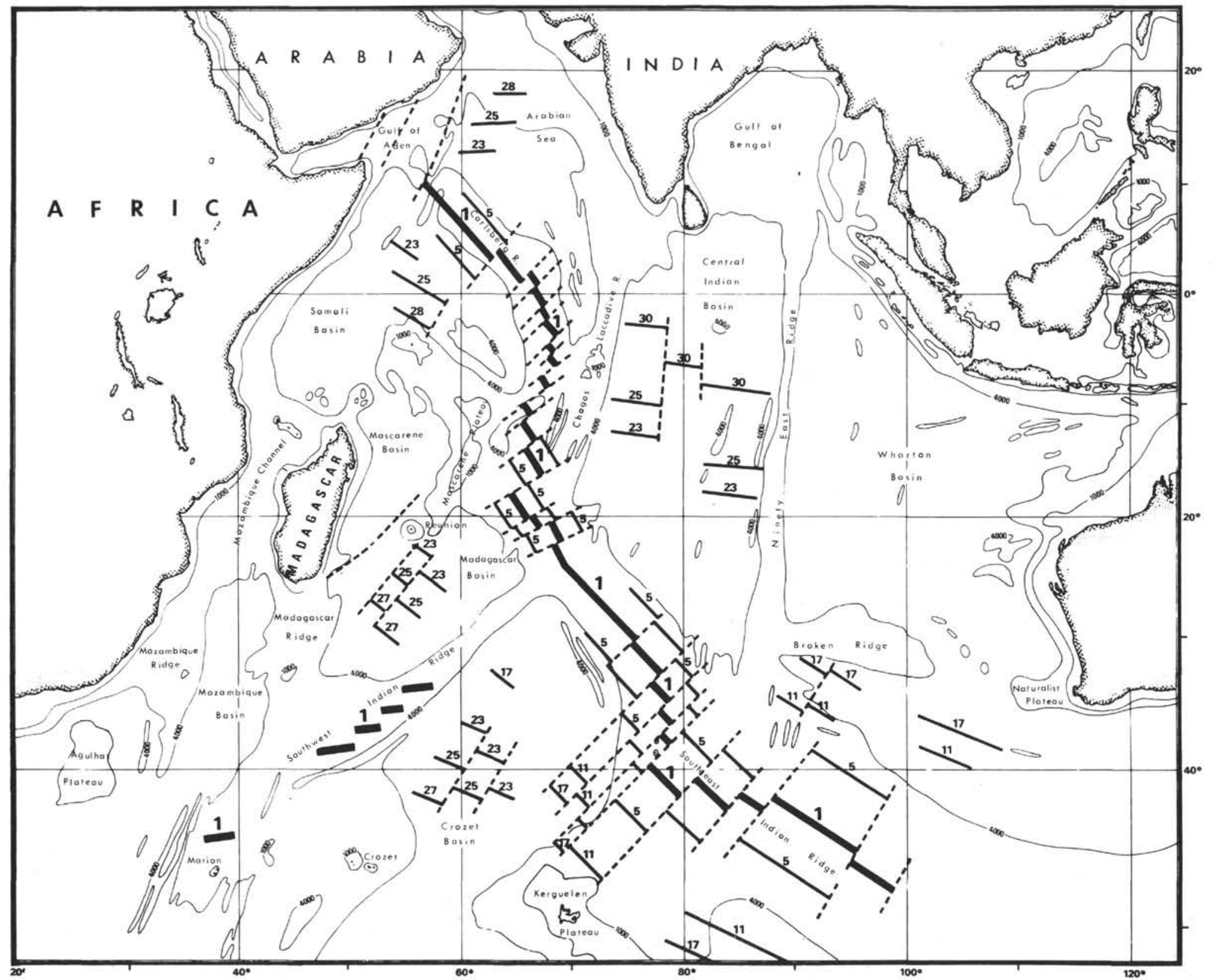

Figure 1. Magnetic lineations in the Indian Ocean; the identifications north of the Mascarene Islands are from McKenzie and Sclater (1971), south of $20^{\circ} \mathrm{S}$ from Schlich and Patriat (1971 a, b, c) and Schlich (1973). The axial magnetic anomalies are shown by thick heavy lines offset by fracture zones (dashed lines). The numbers refer to identified magnetic anomalies according to Heirtzler et al. (1968) time scale. 


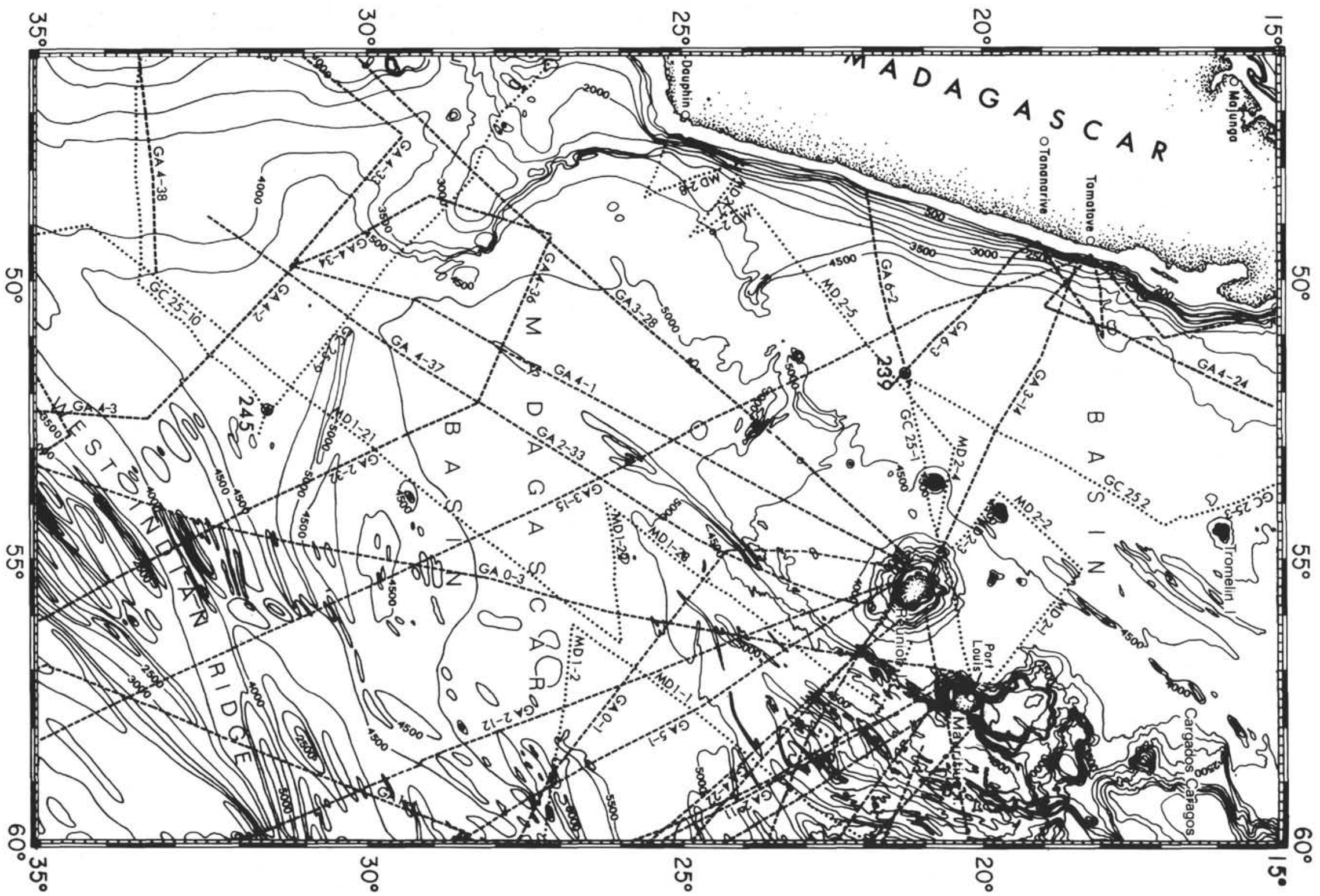

Figure 2. Gallieni, Glomar Challenger (Leg 25), and Marion Dufresne bathymetric and magnetic track chart in the Madagascar and Mascarene basins Gallieni cruises completed prior to DSDP Leg 25 drilling are in dashed lines; Glomar Challenger, Leg 25 (1972) and Marion Dufresne cruises in 1973 are given by dotted lines. The bathymetric contours are from the fold out map published with the Leg 25 Initial Report (Volume 25). 
one-minute intervals on an $\mathrm{x}-\mathrm{y}$ digitizer) assuming a sound velocity for seawater of $1500 \mathrm{~m} / \mathrm{sec}$. The magnetic data were recorded with a Varian proton magnetometer directly in digital form on paper tape. Reduced values, at one-minute intervals, were computed using Cain et al. (1964) GSFC $12 / 66$ and POGO 10/68 coefficients. Ninety thousand miles of profiles were processed in this way; about 16,000 miles of these profiles belong to the area which is considered in this paper $\left(15^{\circ} \mathrm{S}\right.$ to $35^{\circ} \mathrm{S}$ and $46^{\circ} \mathrm{E}$ to $\left.60^{\circ} \mathrm{E}\right)$. The data are available as computer plots of depth and total intensity magnetic anomalies displayed as a function of distance, location, and time (see this volume, Appendix I, for Glomar Challenger profiles). Further, the magnetic anomaly profiles were plotted along the track on a Mercator projection at a scale of $1 / 1850000$ at $33^{\circ} 30^{\prime} \mathrm{S}$ (one degree of longitude equals $4.75 \mathrm{~cm}$ ) and a magnetic anomaly scale of 200 gammas to $1 \mathrm{~cm}$ at right angles to the track. The direction of magnetic lineations was mapped on these charts from correlations between identified magnetic anomalies observed along adjacent tracks. These profiles were then projected along straight lines perpendicular to the strike of the magnetic anomalies and plotted as a function of distance at a horizontal scale of $1 \mathrm{~cm}$ for 20 miles and a vertical scale of $1 \mathrm{~cm}$ for 200 gammas. The spreading rate can be measured from identified magnetic anomalies either on the Mercator chart with the profiles plotted along the tracks or on the projected profiles. The synthetic magnetic anomaly profiles presented in this paper were computed following the method described by Vine (1966) and McKenzie and Sclater (1971) using the Heirtzler et al. (1968) time scale of geomagnetic field reversals, modified beyond anomaly 30 by McKenzie and Sclater (1971, Table 1, p. 469). Synthetic profiles were calculated for different spreading rates and spreading directions, assuming that the anomalies were generated at $20^{\circ}, 30^{\circ}, 40^{\circ}$, and $50^{\circ}$ latitude south and observed at a mean latitude of $25^{\circ} \mathrm{S}$ and a mean longitude of $55^{\circ} \mathrm{E}$. For all these model computations, a thickness of $0.4 \mathrm{~km}$ and a susceptibility of $0.015 \mathrm{cgs}$ were assumed for the basalt layer responsible for the observed magnetic anomalies. For anomalies 23 to 27 , the oceanic crust is supposed to lie at $5.2 \mathrm{~km}$ below sea level, for anomalies 28 to 30 , at $5.3 \mathrm{krn}$, and for anomalies 31 to 33 , at $5.4 \mathrm{~km}$ (Sclater and Francheteau, 1970; Sclater et al.,1971a).

Gallieni tracks (Cruises GA-0 to GA-6) are located by celestial fixes and dead reckoning, and positioning errors of about 3 miles can be expected. Glomar Challenger (Leg 25) and Marion Dufresne (Cruises MD-1 and MD-2) tracks are located by satellite fixes.

\section{SEA FLOOR SPREADING HISTORY IN THE MADAGASCAR AND MASCARENE BASINS}

Madagascar Basin is bounded on the south and southeast by the extremely rough topography of the Southwest Indian Ridge while to the west the basin is limited by the gentle upward slope of the Madagascar Ridge. To the northeast, the southern part of the Central Indian Ridge, and its triple junction with the Southwest and Southeast Indian ridges, marks another boundary for this basin. To the north and northwest, the Madagascar Basin is separated from the Mascarene Basin by a clearly defined fracture zone running west of Reunion Island almost in a northeastsouthwest direction to the southern tip of Madagascar. North of this structure, the Mascarene Basin extends between Madagascar and the Mascarene Plateau towards the Farquhar Group, and the Amirante and Seychelles banks.

Two detailed bathymetric charts, which together cover the area north of $30^{\circ} \mathrm{S}$ and east of $49^{\circ} \mathrm{E}$, have been published by Fisher et al. (1967, 1971). A clear northeast-southwest bathymetric trend can be observed on both charts west of the Mascarene Plateau and south of the Mascarene Islands. To map as precisely as possible the different fracture zones across the Madagascar and Mascarene basins, all bathymetric profiles obtained by Gallieni, Glomar Challenger (Leg 25), and Marion Dufresne were carefully examined using the computer plot depth profiles displayed as a function of distance, location, and time. About 30 tracks are more or less in a northwestsoutheast or north-south direction, and a clear succession of fracture zones can be seen on these profiles (see for instance, Figure 3). All of these fracture zones were positioned along their corresponding ship's tracks on a Mercator projection chart. The magnetic profiles also were considered since interruptions of magnetic anomaly patterns can be used as indicators of fracture zone positions (Figure 3). From south to north, all profiles show an extremely rough topography which is associated with the Southwest Indian Ridge, and the boundary with the Madagascar Basin is clearly delineated by the characteristics of the bottom relief. Magnetic profiles recorded along these tracks show significant changes upon entering the Madagascar Basin, depending, of course, on the orientation of the profiles. However, for a north-south profile, short wavelength magnetic anomalies related to the Southwest Indian Ridge are progressively replaced by relatively long wavelength anomalies associated with spreading from the Central Indian Ridge (Figure 3). Three well-established fracture zones, nearly parallel to the general northeastsouthwest topographic trend of the Southwest Indian Ridge, were traced throughout the Madagascar and Mascarene basins. To the south, their directions are about $50^{\circ} \mathrm{E}$; then the directions change progressively to $38^{\circ} \mathrm{E}$ and finally to $47^{\circ} \mathrm{E}$ in the northern part of the Madagascar Basin. These fracture zones have been labeled from the south to the north A, B, and C (Figure 5). Fracture zone C, which lies west of Reunion Island, separates the Madagascar and Mascarene basins and unofficially has been named the Mahanoro Ridge (Conrad 14 Cruise) and is without doubt one of the most striking features in that area. Figure 4 shows several bathymetric profiles (MD2-1, MD2-3, GA3-14, MD2-4, GC25-1, GA3-15, MD2-6, and MD2-7) projected along straight lines at right angles to the mean strike $\left(45^{\circ} \mathrm{E}\right)$ of fracture Zone $\mathrm{C}$. This fracture can be traced without difficulty from $18^{\circ} \mathrm{S}$ to $23^{\circ} \mathrm{S}$; close to Madagascar, the proposed trend is tentative and is based on the data collected at $25^{\circ} \mathrm{S}$ (MD2-6, MD2-7, and MD2-8). North of this structure in the Mascarene Basin, it is possible from the bathymetric charts of Fisher et al. (1967 and 1971) and from several profiles collected in that area (Figure 2), to sketch, southeast of Tromelin Island between $16^{\circ} \mathrm{S}$ and $22^{\circ} \mathrm{S}$ and towards Madagascar, a northnortheast-south-southwest trending fracture zone (D); 


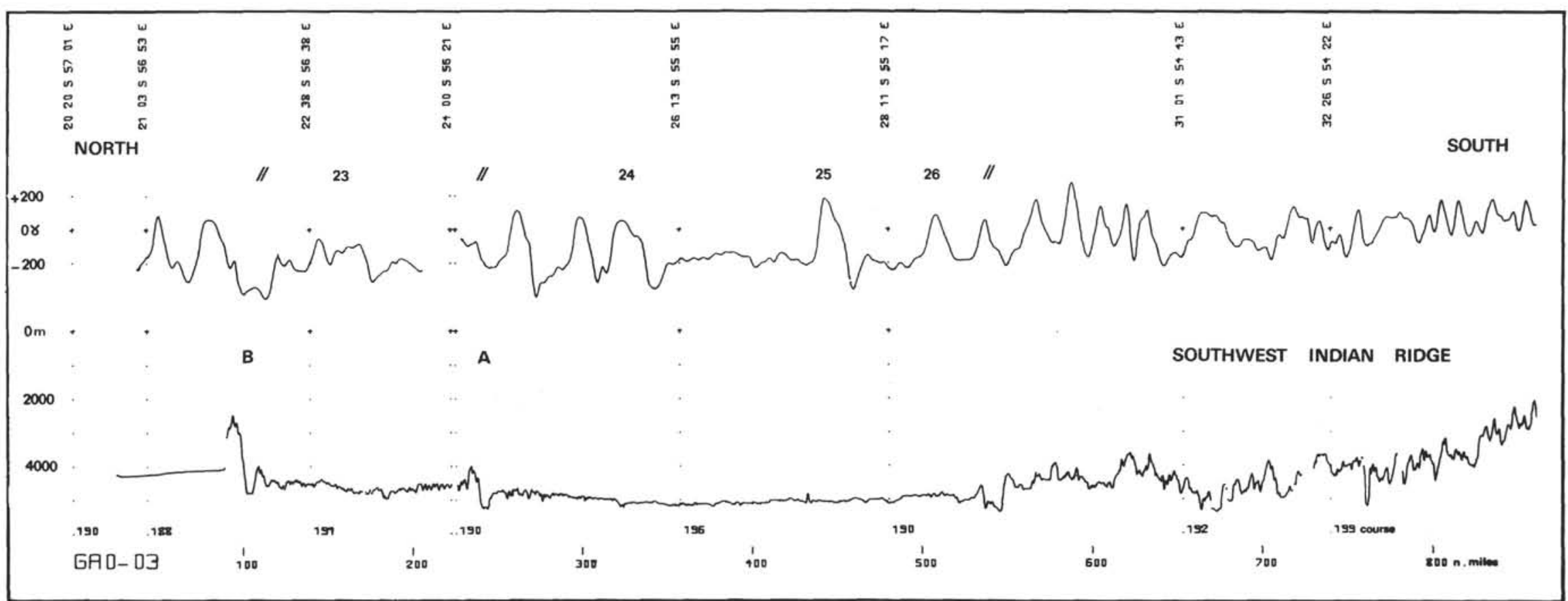

Figure 3. Gallieni (GAO-3) bathymetric and magnetic profile across the Madagascar Basin toward the Southwest Indian Ridge. The letters (A and B) correspond to the location of the fracture zones which were crossed along this track. The numbers are identified magnetic anomalies and the dash marks indicate interruptions of magnetic anomaly pattern. 


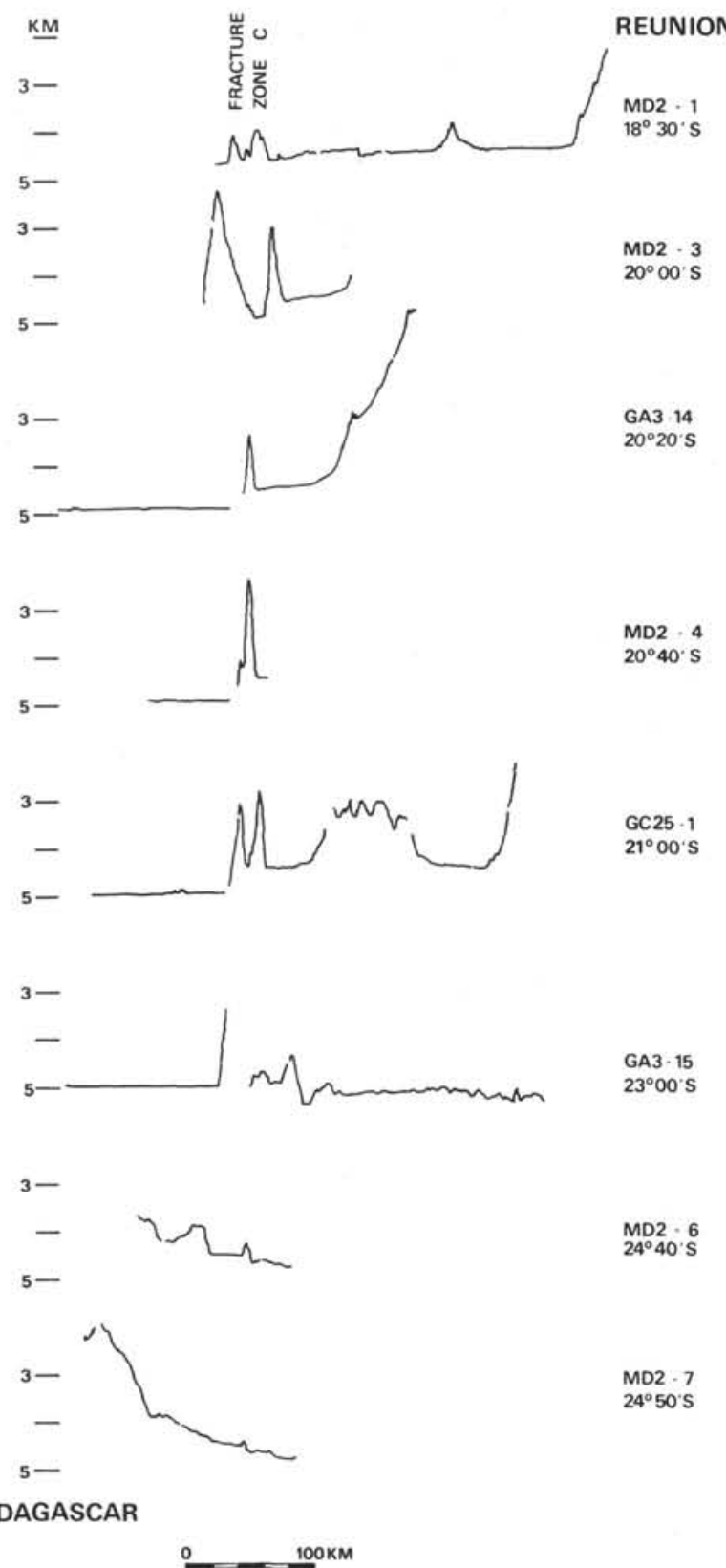

Figure 4. Gallieni (GA3-14 and GA3-15), Glomar Challenger (GC25-1), and Marion Dufresne (MD2-1, MD2-3, MD2-4, MD2-6 and MD2-7) bathymetric profiles across the Mahanoro fracture zone (C) projected perpendicular to the strike of the fracture. The depths are given in kilometers. The latitudes of intersection of the fracture zone with the track are given with the code number of the corresponding bathymetric profile.

however, complementary data are required to map this fracture zone toward Madagascar (Figure 5).

Magnetic anomalies can be identified in the Madagascar Basin along several northeast-southwest or north-south lines (GA0-3, GA2-33, GA3-28, GA4-1, MD1-1, MD1-21, and MD1-23). In the Mascarene Basin, long northeast-southwest profiles are not available; nevertheless, the identification of magnetic anomalies is possible (GA6-2, GC25-1, GC25-2, MD2-2, and MD2-5). These data are complemented by several profiles published by Sclater et al. (1971b): in the Madagascar Basin, $\mathrm{C} 11$ between $32^{\circ} \mathrm{S}$ and $22^{\circ} \mathrm{S}$ and V20 between $26^{\circ} \mathrm{S}$ and $20^{\circ} \mathrm{S}$; and in the Madagascar and Mascarene basins, V18 between $28^{\circ} \mathrm{S}$ and $18^{\circ} \mathrm{S}$. In the first compartment, limited by the rough topography of the Southwest Indian Ridge and by fracture zone A, anomalies 29 through 21 are easily recognized; anomaly 30 is doubtful. The strikes of their lineations are given first by C11 and MD1-21 (anomalies 29 to 27), then by GA0-3, C11, MD1-21, and MD1-1 (anomalies 26 to 23). Anomalies 22 and 21 can be traced by $\mathrm{C} 11$ and MD1- 1 profiles. To the north, younger anomalies can still be identified on profile MD1-1, but from this single line, which does not extend further than $20^{\circ} \mathrm{S}$, it is neither possible to propose precise identifications nor to map the trend of these anomalies. Between fracture zones A and B, only a single line allows identification of anomalies 29, 28, and 27 (GA4-37 continued to the northeast by GA2-33); anomalies 26 through 23 are observed on several profiles, and their strikes are well established. From V20 and Marion Dufresne (MD1-22 and MD1-23) profiles, it can be ascertained that the GA2-33 profile should be shifted about 5 to 10 miles to the south; this can easily be explained since navigation at this time was performed by celestial fixes and dead reckoning and the track was located according to only two fixes, about 22 hours apart. Again, anomaly 22 is clearly recorded at the northern end of profile MD1-23, which in turn is interrupted at about $21^{\circ} 40^{\prime} \mathrm{S}$. The right lateral offset of the anomaly pattern on both sides of fracture zone A is about $150 \mathrm{~km}$. In the next compartment between fracture zones B and C, anomalies 28 and 29 directly southwest of Reunion Island, are clearly recorded and their strikes are obtained from two northeast-southwest lines (GA3-28 and GA4-1). Further to the south, older anomalies can be recognized on both profiles, but their identifications are somewhat uncertain. However, anomaly 32 , and possibly anomaly 33 , can be located with some confidence, mainly by using the GA4-1 track. If these identifications are correct, the right lateral offset by fracture zone B, measured from anomalies 28 and 29 , is about $670 \mathrm{~km}$. North of the Mahanoro fracture (C), anomalies 33 to 31 are clearly identified and the strike of the magnetic lineations is given by several Gallieni, Glomar Challenger, and Marion Dufresne profiles (GA6-2, GC25-1, GC25-2, MD2-5), complemented by the V18 north-northeast-southsouthwest line. Anomalies younger than 30 are not recorded; profile MD2-5 is interrupted at anomaly 30 , profile MD2-2 to the north is too short to allow any identification, and Glomar Challenger GC25-2 track and the V18 line are already too close to the next fracture zone, which offsets the magnetic pattern (Figure 5). All the magnetic anomaly profiles which are used for these interpretations are given in Figure 6 and are projected at right angles along the ship tracks. The numbers correspond to the scheme proposed by Pitman and Heirtzler (1966) and Heirtzler et al. (1968) for magnetic anomalies produced by sea floor spreading; the solid lines give the corresponding orientation of these anomalies. Anomalies 33, 32, and possibly 31 , strike $138^{\circ} \mathrm{E}$; the trend of anomaly 31 is 


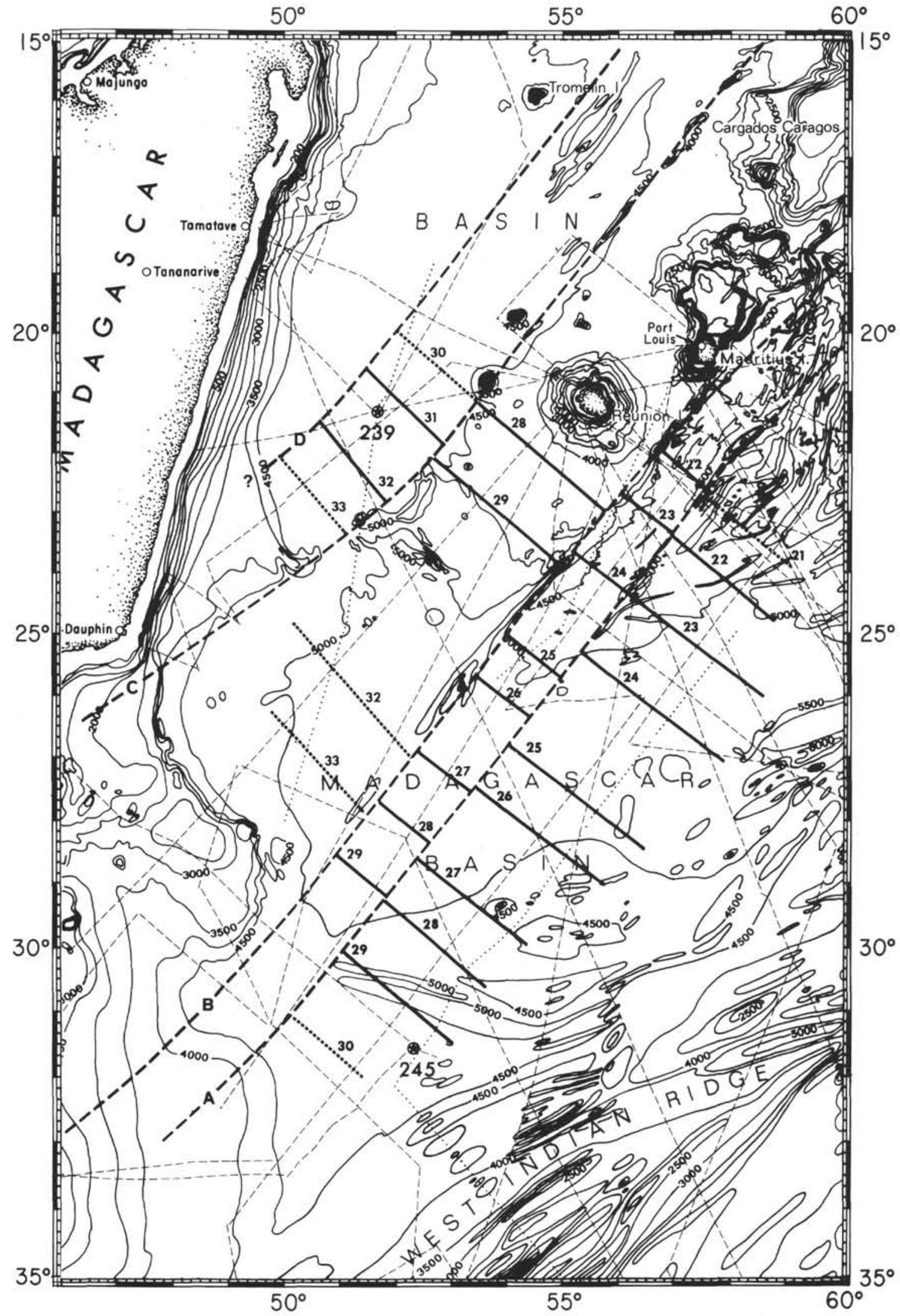

Figure 5. Fracture zones and magnetic lineations in the Madagascar and Mascarene basins. The successive fracture zones are labelled from south to north $\mathrm{A}, \mathrm{B}, \mathrm{C}$ and $\mathrm{D}$; the numbers correspond to identified magnetic anomalies. The bathymetric contours are from the fold out chart published with the Leg 25 Initial Report (Volume 25). 


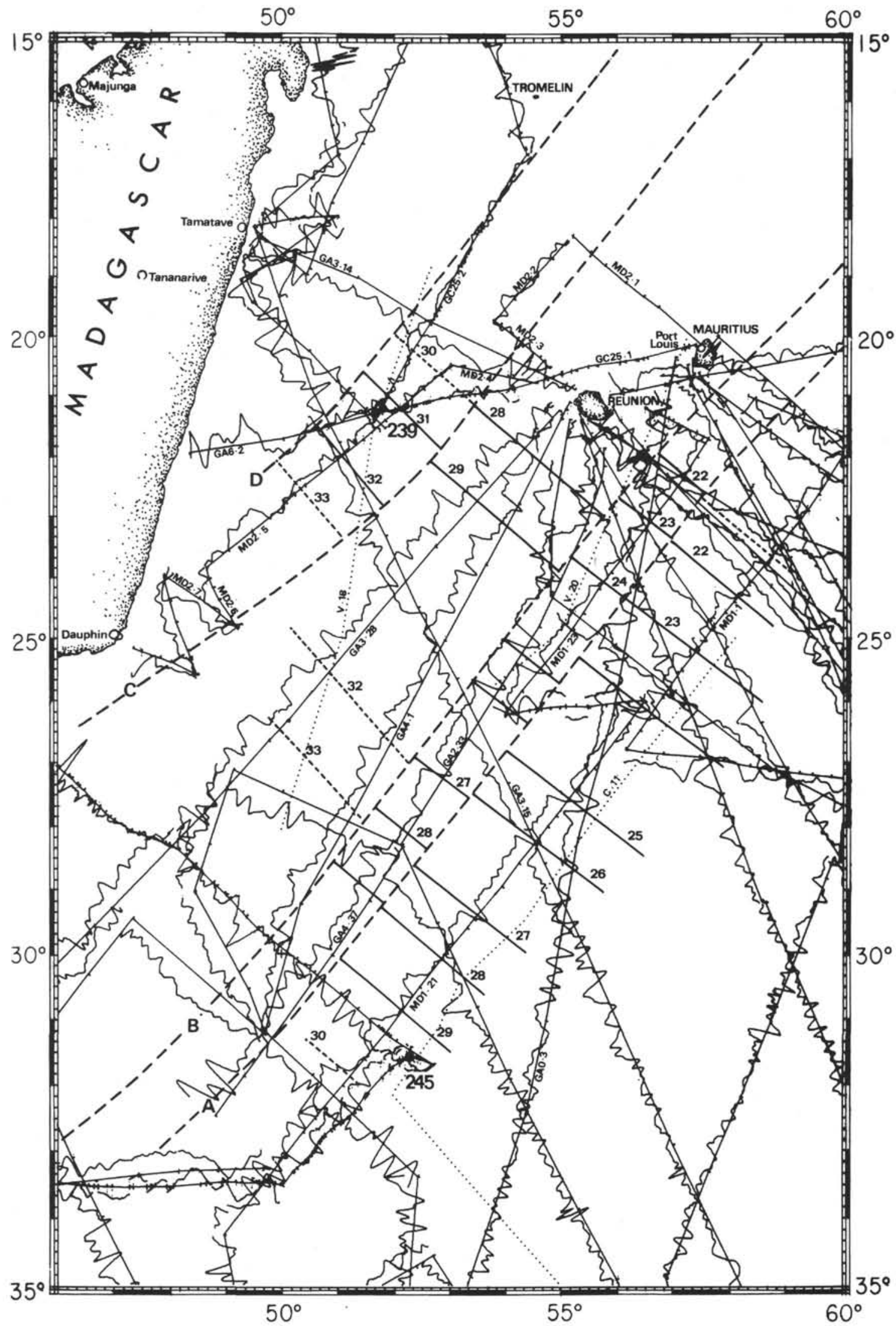

Figure 6. Magnetic anomalies plotted at right angles to the ship tracks in the Madagascar and Mascarene basins $\left(15^{\circ} \mathrm{S}\right.$ to $35^{\circ} \mathrm{S}$ and $46^{\circ} \mathrm{E}$ to $\left.60^{\circ} \mathrm{E}\right)$. Identified magnetic anomalies are numbered according to Heirtzler et al. (1968) scheme. 
somewhat uncertain since only four closely spaced tracks in the Mascarene Basin show this anomaly. Anomalies 29 and 28 strike $130^{\circ} \mathrm{E}$, and the strike of anomalies 27 through 23 is $127^{\circ} \mathrm{E}$.

On the basis of these interpretations and results, spreading rates were calculated. Synthetic magnetic anomaly profiles, computed for different spreading rates, as explained in the first part of this paper, were compared to the observed magnetic profiles projected along straight lines perpendicular to the magnetic anomaly strikes. Anomalies 33 to 31 (79 to 71 m.y. B.P.) were formed at a spreading (half) rate of about $4.0 \mathrm{~cm} / \mathrm{yr}$; this value was mainly derived from the data collected in the southern Mascarene Basin. In the Madagascar Basin, where anomalies 31 and 30 could not be identified with enough certainty, it is somewhat hazardous to calculate a spreading rate. Though the observed profiles in the Mascarene Basin do not extend very far, the agreement between the calculated and observed profiles in Figure 7 appears very good. The model

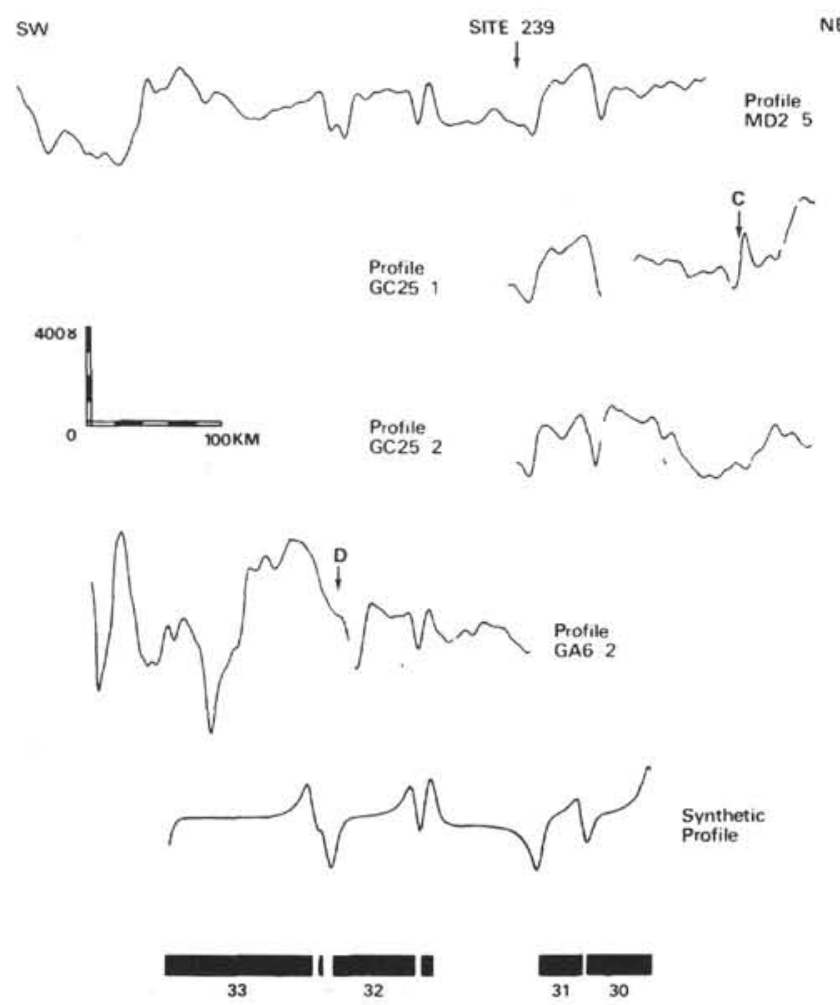

Figure 7. Magnetic anomaly profiles in the Mascarene Basin, projected at $48^{\circ} \mathrm{E}$. The synthetic profile is computed for a ridge striking $130^{\circ} \mathrm{E}$ at a latitude of $20^{\circ} \mathrm{S}$ with a spreading rate of $4.0 \mathrm{~cm} / \mathrm{yr}$. and observed at $25^{\circ} \mathrm{S}$ and $55^{\circ} \mathrm{E}$.

was computed for a ridge striking $130^{\circ} \mathrm{E}$ at a latitude of $20^{\circ} \mathrm{S}$ and observed at $25^{\circ} \mathrm{S}$ and $55^{\circ} \mathrm{E}$. The locations of fracture zones $\mathrm{C}$ and $\mathrm{D}$, which interrupt the magnetic pattern, are indicated on Figure 7 along the corresponding profiles. For anomalies 30 to 28 (71 to 67.5 m.y. B.P.), observed in the Madagascar Basin, the spreading (half) rate is $12.2 \mathrm{~cm} / \mathrm{yr}$. This is a mean value derived from observations made in the northern part of the Madagascar Basin between fracture zones B and C and in the southern part of this basin between fracture zones A and B. The agreement of observed data, at least for anomalies 29 and 28 , with the synthetic profile computed for a ridge striking $130^{\circ} \mathrm{E}$ at a latitude of $40^{\circ} \mathrm{S}$ and again observed at $25^{\circ} \mathrm{S}$ and $55^{\circ} \mathrm{E}$ is good (Figure 8). On profile MD1-21, at the top of Figure 8 , the arrow on the left indicates the point where the track runs into the Southwest Indian Ridge rugged topography. A very clear change of spreading rate occurs near anomaly 27 (about 67.5 m.y. B.P.). This change is clearly demonstrated on Figure 8 by the shorter distance between anomalies 28 and 27 on the two uppermost profiles (MD1-21 and GA2-33) compared to the proposed model computed with a spreading (half) rate of $12.2 \mathrm{~cm} / \mathrm{yr}$. Between anomalies 27 and 23 (about 68 to 58 m.y. B.P.), the spreading (half) rate decreases to $7.1 \mathrm{~cm} / \mathrm{yr}$. This value for the Madagascar Basin is well established since all observed profiles in that area yield the same results. The agreement between the observed data and the proposed model is excellent (Figure 9). The synthetic profile was computed for a ridge striking $130^{\circ} \mathrm{E}$ at a latitude of $40^{\circ} \mathrm{S}$ and observed, as for the previous model, at $25^{\circ} \mathrm{S}$ and $55^{\circ} \mathrm{E}$. Profile GA0-3, from northeast to southwest, first crosses fracture zone A, shows anomalies 24,25 , and part of 26 , and then runs into the Southwest Indian Ridge system. To the northeast, anomaly 23 , offset by fracture zone A, can be seen at the very beginning of this profile. On profile GA2-33, fracture zone B, south of Reunion Island, interrupts the magnetic pattern just after anomaly 25 . Another change in spreading rate occurs near anomaly 22, 57 m.y. B.P. (see Figure 9); but as already explained, the data available in the Madagascar Basin do not allow, at least at present, the identification of anomalies younger than anomaly 19 . These younger anomalies have been identified in the northern part of the Crozet Basin (Schlich, in preparation) and show the same spreading rate change near anomaly 22 where the spreading (half) rate decreases to about $4.0 \mathrm{~cm} / \mathrm{yr}$. Farther to the north, at about anomaly 17 (43 m.y. B.P.), the spreading (half) rate decreases still more to a value of about $2.5 \mathrm{~cm} / \mathrm{yr}$. If it is assumed that the magnetic lineations for these younger anomalies have the same strike in the Crozet and Madagascar basins, a spreading (half) rate of about $4.0 \mathrm{~cm} / \mathrm{yr}$ can be calculated for anomalies 22 to 19 in the Madagascar Basin.

Though the magnetic profiles given in Figures 7, 8, and 9 are in good agreement with the synthetic profiles computed with the Heirtzler et al. (1968) time scale, small systematic differences can be observed. Since these differences were also recorded on profiles located further south in the Crozet Basin, they may, if also seen in other oceans, correspond to earth magnetic field reversals which were not identified on the South Atlantic V-20 profile upon which the Heirtzler et al. (1968) time scale is based. Anomaly 23, which is clearly recorded on profiles MD1-1 and MD1-23, and on profile GA0-3 with an offset by fracture zone A (Figure 9), appears slightly displaced to the right compared to the model; this may be, of course, explained by a slight difference in spreading rate, but the most striking fact is the existence of a short negative event of about 0.06 m.y. within the positive period corresponding to this anomaly. Beyond anomaly 23, and between the next positive period and anomaly 24, all the profiles in the Madagascar 

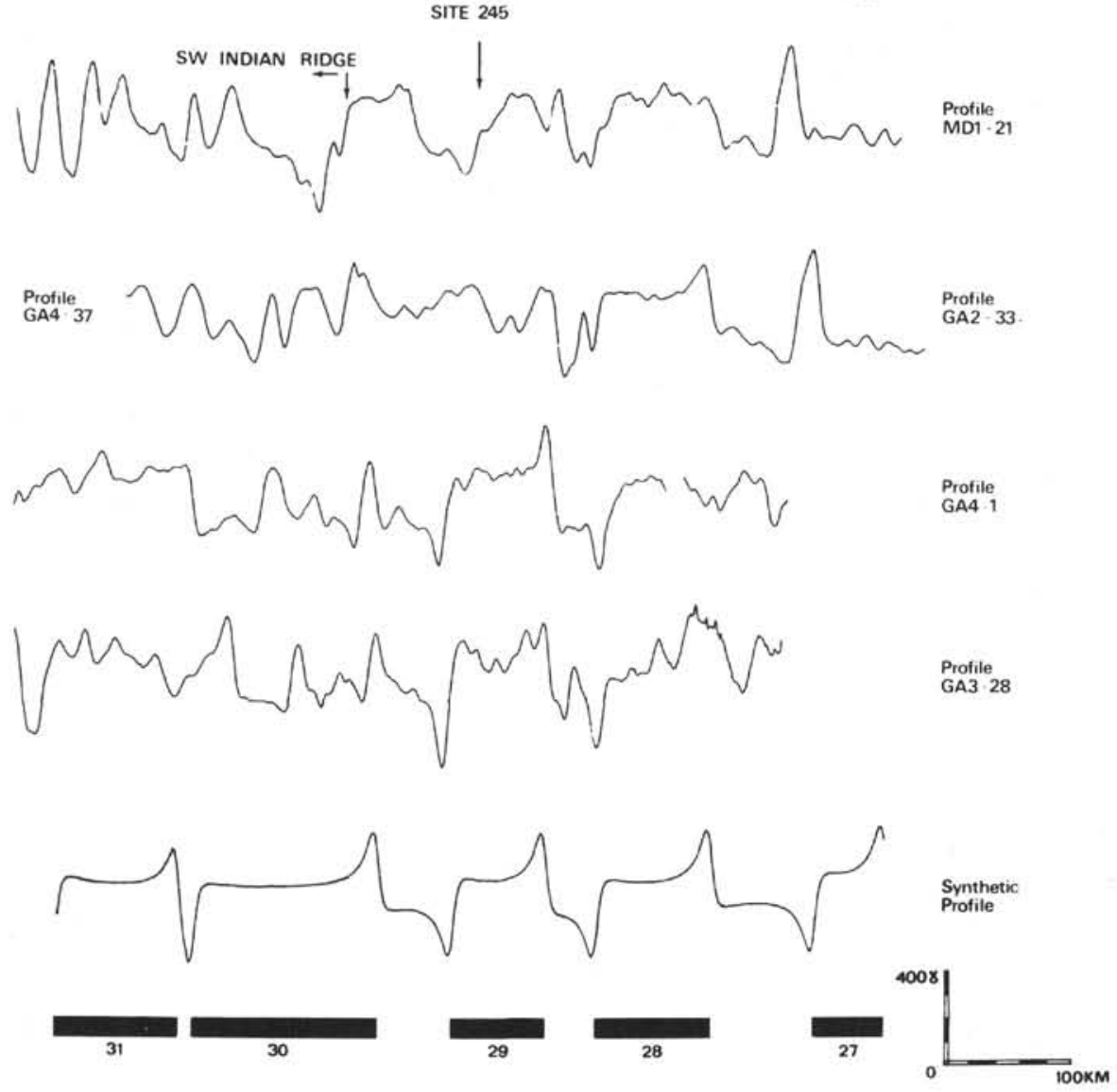

Figure 8. Magnetic anomaly profiles in the Madagascar Basin, projected at $40^{\circ} \mathrm{E}$.

The synthetic profile is computed for a ridge striking $130^{\circ} \mathrm{E}$ at a latitude of

$40^{\circ} \mathrm{S}$ with a spreading rate of $12.2 \mathrm{~cm} / y$ r. and observed at $25^{\circ} \mathrm{S}$ and $55^{\circ} \mathrm{E}$.

(Figure 9) and Crozet basins show a clear positive event of about 0.03 m.y. These two short events were pointed out to the author by Patriat (personal communication). Moreover, between the positive period corresponding to anomalies 28 and 29, a clear positive event of about 0.03 m.y. also is recorded on profiles MD1-21, GA4-37, GA4-1, and GA3-28 (Figure 8). It is also noteworthy to record that the modifications proposed by McKenzie and Sclater (1971), table 1, page 469) beyond anomaly 30, and, mainly, the existence of a short positive event of 0.05 m.y. in the negative period between anomalies 32 and 33, also appear on the Gallieni and Marion Dufresne profiles: profile MD2-5 (Figure 7) and profile GA4-1 at about $27^{\circ} \mathrm{S}$ (Figure 6).

Observed magnetic anomalies are dependent on the latitude at which they were formed. Since it can be assumed that the direction and magnetization of sea floor basalts are stable and do not change with motion of the plate to which they belong, it is possible, by further assuming a steady mean dipole magnetic field configuration, to estimate, by comparison of observed magnetic anomalies with synthetic profiles computed for different latitudes, the relative motion between the plate on which these anomalies were recorded and the earth's axis. In the southern Mascarene Basin, the slope and amplitude of the observed anomalies (MD2-5) lead to the conclusion that they were generated between $20^{\circ} \mathrm{S}$ and $30^{\circ} \mathrm{S}$. Figure 10 shows several synthetic profiles computed for a ridge striking $130^{\circ} \mathrm{E}$ and generated at $20^{\circ} \mathrm{S}, 30^{\circ} \mathrm{S}$, and $40^{\circ} \mathrm{S}$. The best fit with the observed magnetic profile, at the top of the figure (anomalies 32/31), may be obtained for a latitude of about $25^{\circ} \mathrm{S}$. In the Madagascar Basin, a composite profile, MD-21, extended to the northeast by MD1-1, is compared to several synthetic profiles computed for a ridge striking $130^{\circ} \mathrm{E}$ and created at $20^{\circ} \mathrm{S}, 30^{\circ} \mathrm{S}$, and $40^{\circ} \mathrm{S}$ (Figure 11). The best fit of the observed magnetic profile with the synthetic profiles, for anomalies 27 to 25 , formed $67 / 63$ m.y. B.P., is obtained if one assumes that these anomalies were formed at $40^{\circ} \mathrm{S}$. Finally, in the Mascarene Basin, anomalies $32 / 31$ were generated at a latitude which corresponds about to the latitude at which they are now observed. Anomalies 27/25 in the Madagascar Basin were formed at about $40^{\circ} \mathrm{S}$ and are now recorded between $25^{\circ} \mathrm{S}$ and $30^{\circ} \mathrm{S}$. Since the ridge crest material in both basins is spreading in a southwest direction, it is clear from these observations that relative to the earth's axis, assuming that the geomagnetic field when averaged can be represented by an axial dipole field, there was a general northward drift during Cenozoic time of about $20^{\circ}$ of latitude.

Figure 12 summarizes the principal results given in this paper for the Mascarene and Madagascar basins. The data 

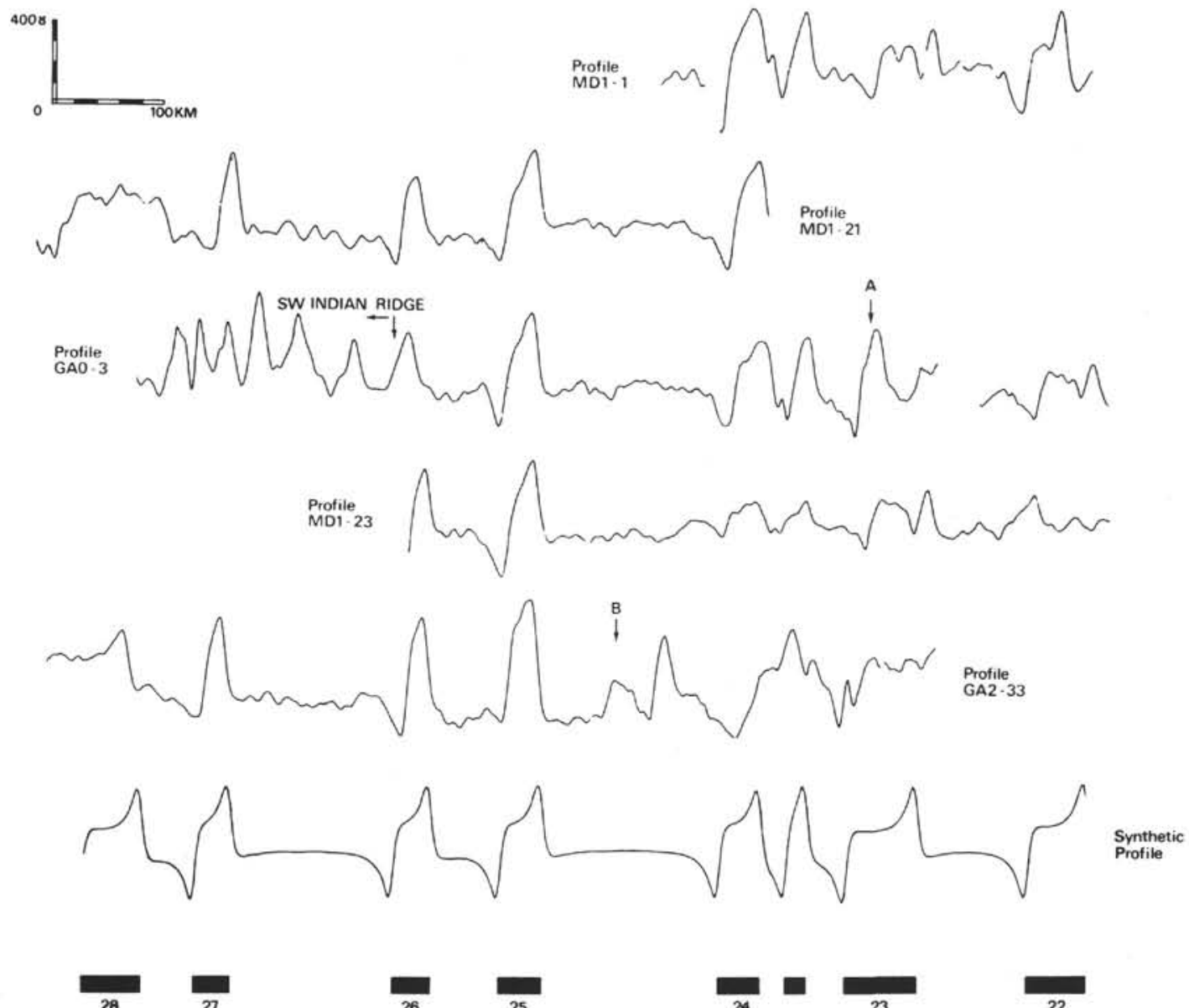

27

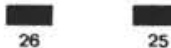

$24 \square-23$

22

Figure 9. Magnetic anomaly profiles in the Madagascar Basin, projected at $37^{\circ} \mathrm{E}$. The synthetic profile is computed for a ridge striking $130^{\circ} \mathrm{E}$ at a latitude of $40^{\circ} \mathrm{S}$ with a spreading rate of $7.1 \mathrm{~cm} / \mathrm{yr}$. and observed at $25^{\circ} \mathrm{S}$ and $55^{\circ} \mathrm{E}$.
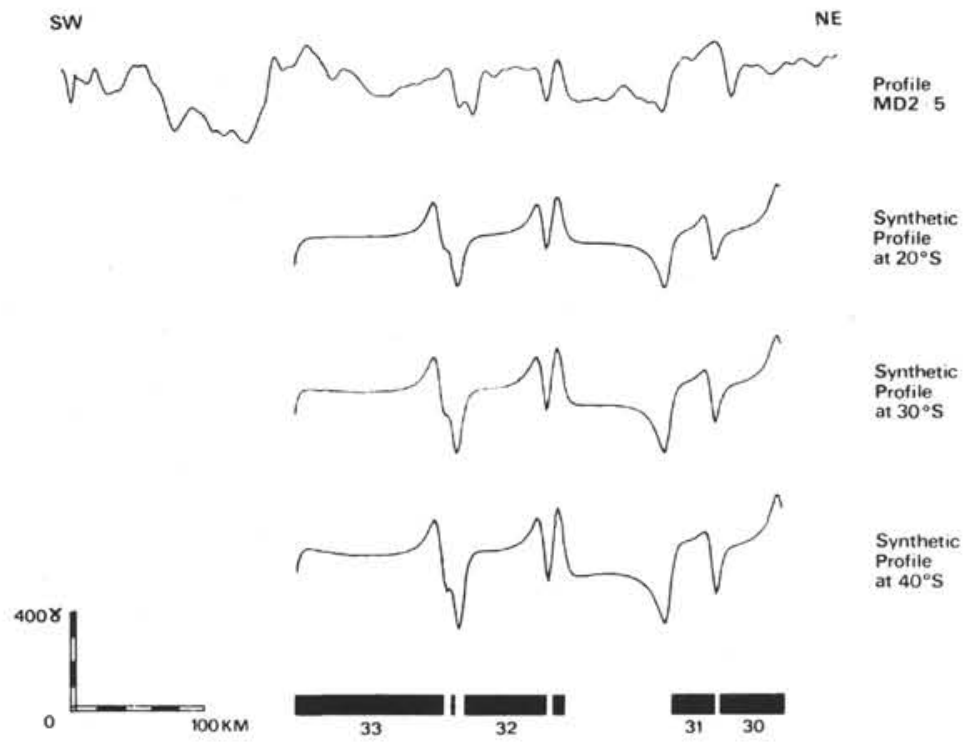

Figure 10. Magnetic anomaly profile MD2-5 in the Mascarene Basin, projected at $48^{\circ} \mathrm{E}$, compared to synthetic profiles calculated for a ridge striking $130^{\circ} \mathrm{E}$, generated at $20^{\circ} \mathrm{S}, 30^{\circ} \mathrm{S}$ and $40^{\circ} \mathrm{S}$ with a spreading (half) rate of $4.0 \mathrm{~cm} / \mathrm{yr}$. and observed at $25^{\circ} \mathrm{S}$ and $55^{\circ} \mathrm{E}$ with a strike of $130^{\circ} \mathrm{E}$. 
sw

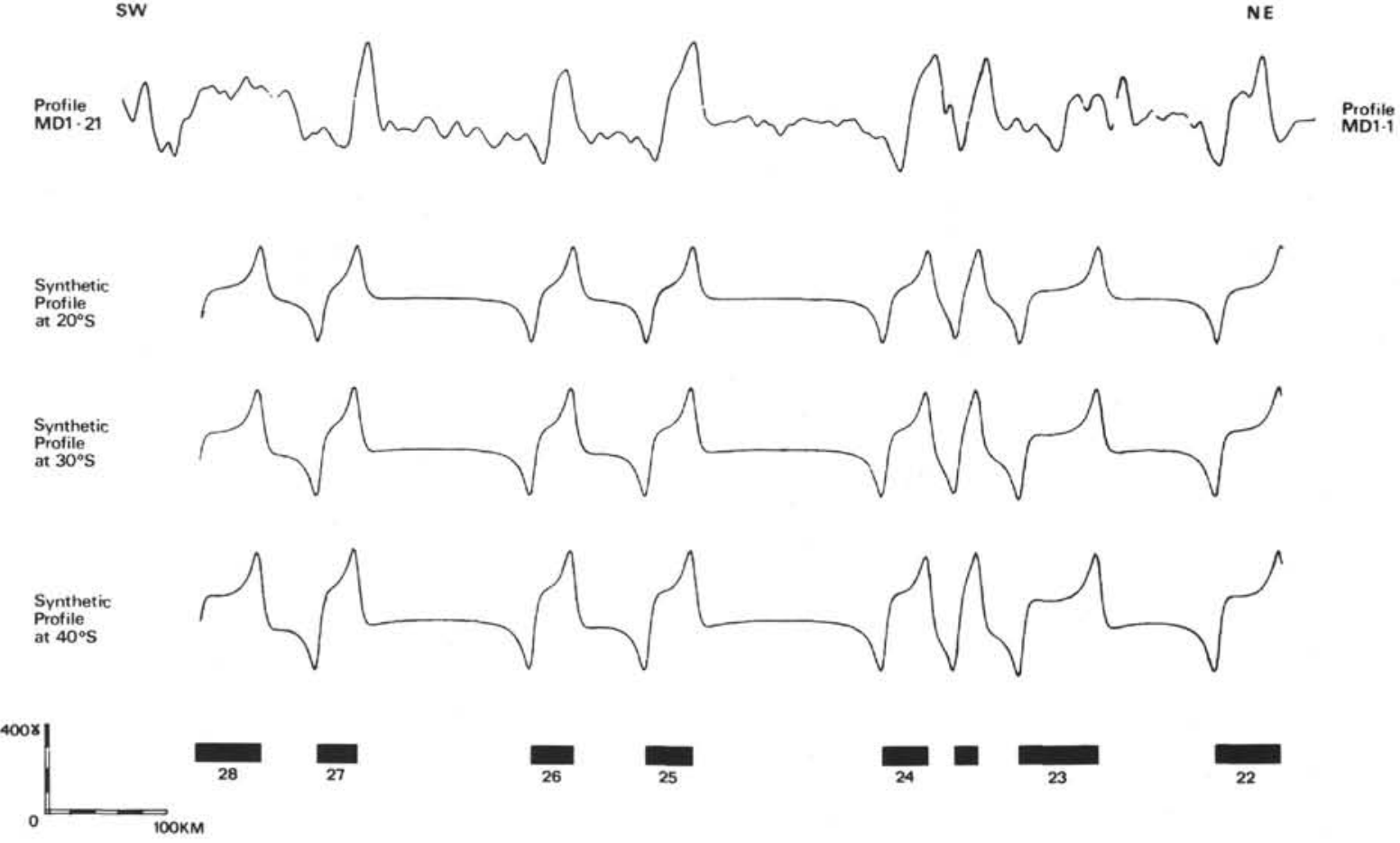

Figure 11. Magnetic anomaly composite profile (MD1-21 and MD1-1) in the Madagascar Basin, projected at $37^{\circ} \mathrm{E}$, compared to synthetic profiles calculated for a ridge striking $130^{\circ} \mathrm{E}$, generated at $20^{\circ} \mathrm{S}, 30^{\circ} \mathrm{S}$ and $40^{\circ} \mathrm{S}$ with a spreading (half) rate of $7.1 \mathrm{~cm} / \mathrm{yr}$. and observed at $25^{\circ} \mathrm{S}$ and $55^{\circ} \mathrm{E}$ with a strike of $130^{\circ} \mathrm{E}$.

for the Central Indian Ridge and the south part of the Central Indian Ocean are from McKenzie and Sclater (1971); the data for the Southwest Indian Ridge are from Schlich and Patriat (1971b); the data for the Southeast Indian Ridge are from Schlich and Patriat (1971a); and the sketch given for the Corzet Basin is provisional (Schlich, 1973, and Schlich, in preparation).

\section{DEEP-SEA DRILLING RESULTS AND DISCUSSIONS}

Two sites, one in the Mascarene Basin (Site 239: $21^{\circ} 18^{\prime} \mathrm{S}$ and $\left.51^{\circ} 41^{\prime} \mathrm{E}\right)$ and the other in the Madagascar Basin (Site 245: $31^{\circ} 32^{\prime} \mathrm{S}$ and $52^{\circ} 18^{\prime} \mathrm{E}$ ) were drilled during Deep Sea Drilling Project, Leg 25 in the western Indian Ocean (Schlich et al., this volume, Chapters 2 and 7). The major objectives of this drilling was to establish the age of the basement in order to provide for Site 239, in the Mascarene Basin, a baseline for the interpretation of future magnetic data, and to check at Site 245, in the Madagascar Basin, the magnetic pattern proposed by Schlich and Patriat (1971c) and Schlich et al. (1972).

Site 239 is located at a water depth of 4971 meters in the abyssal plain of the southern Mascarene Basin, 180 miles east of Madagascar and 200 miles west of Reunion Island. The hole penetrated 320 meters of Pleistocene to upper Campanian sediments and 6 meters into the underlying basaltic basement. The dark gray basalt which was recovered is fine-grained, partly glassy, and similar in composition to the low-K tholeiites recovered from mid-oceanic ridges (Erlank and Reid, this volume). The sediments in contact with the basalt show no signs of baking or other alteration, and the basalt can be considered to form true "oceanic basement." From the biostratigraphic information, the basaltic basement is established as pre-late Campanian (> 71 to 73 m.y. according to the time scale used in this volume, Chapter 1). Site 239 lies on the older side (south) of anomaly 31 , which has been clearly identified in the Mascarene Basin, first on profile MD2-5 and later on profile GC25-1 and GC25-2 (see Figure 7). According to the Heirtzler et al. (1968) magnetic time scale, complemented by McKenzie and Sclater (1971, table 1 , page 469), anomaly 31 was formed between 71.2 and 72.0 m.y. B.P. The correspondence of this $72 \mathrm{~m} . \mathrm{y}$. magnetic age with the biostratigraphic age obtained from both nannofossils and foraminifera is surprisingly good and should be taken into consideration when attempts are made to update the present magnetic time scale.

Site 245 is located in the southern Madagascar Basin at a water depth of 4857 meters, about 300 miles east of the Madagascar Ridge crest and about 200 miles northwest of the Southwest Indian Ridge axis; but according to the magnetic data collected in that area, it is beyond the limit of oceanic crust formed by spreading from the latter ridge. The hole penetrated 389 meters of sediments, which extends back in time to early Paleocene. Below the sediments, basaltic basement was cored between 389 and 396.5 meters. Recovery in this interval was very poor; dark glassy to fine-grained basalt fragments were first recovered with inclusions of a gray medium-grained diabasic basalt which in composition is similar to the low-K tholeiites of oceanic ridges (Erlank and Reid, this volume). The lower part of the cored basalt (diabase) appears fresh and unaltered but, unfortunately, neither the contact between the two texturally different basalts nor the contact with the 


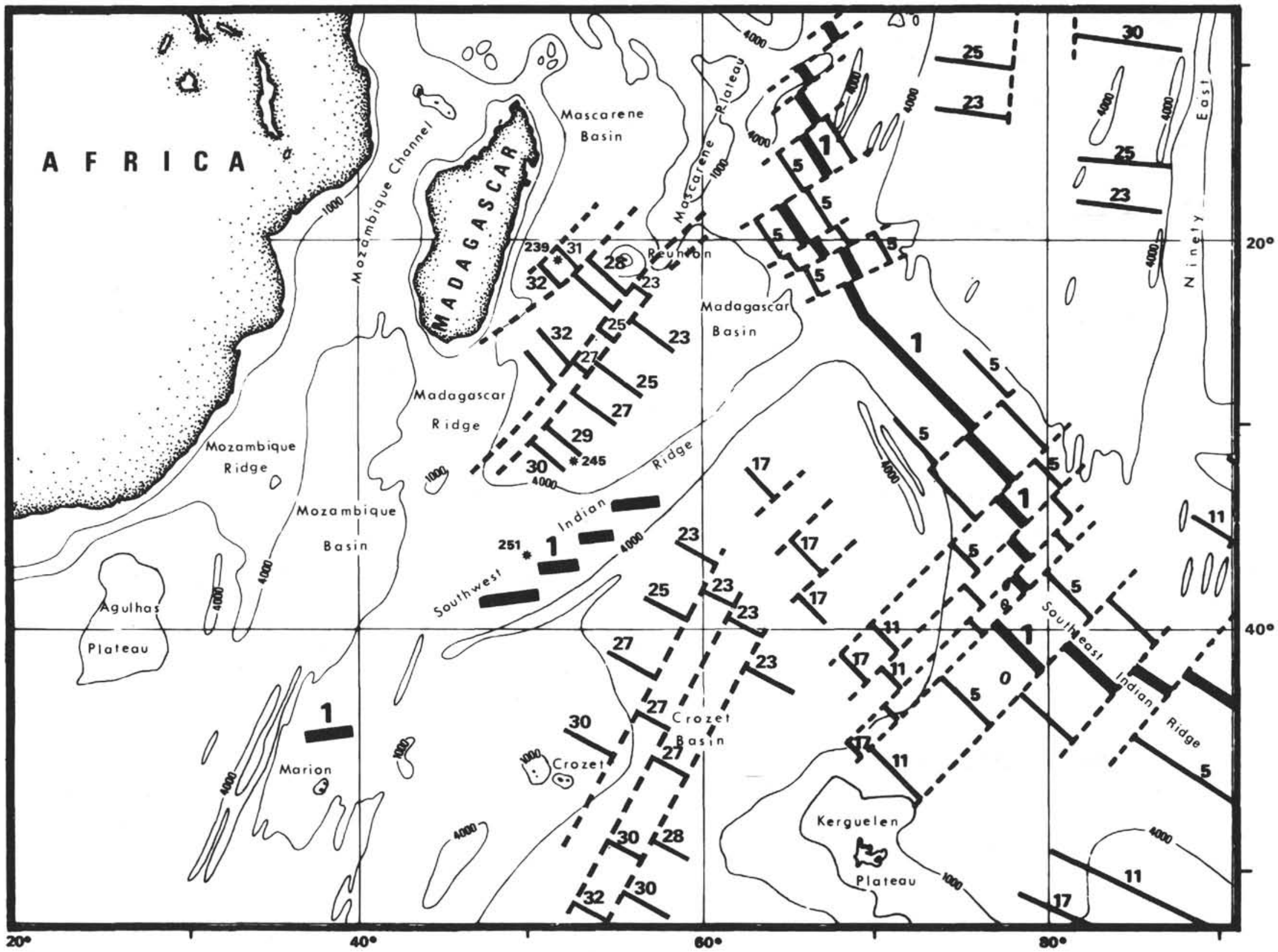

Figure 12. Summary diagram showing the magnetic lineations in the southwestern Indian Ocean. The axial magnetic anomalies are shown by thick heavy lines offset by transform fault (dashed lines). The numbers refer to identified magnetic anomalies according to Heirtzler et al. (1968) time scale. The data given in the Crozet Basin are provisional (Schlich, in preparation). 
overlying sediments were recovered. McKee (this volume) dated the diabasic basalt by the $\mathrm{K} / \mathrm{Ar}$ method and found an age of $27 \pm 3 \mathrm{~m} . y$., thereby establishing its intrusive origin. The lowest sediments cored were confidently dated by nannofossils and foraminifera as early Paleocene (middle Danian) with an age of 61 to $63 \mathrm{~m} . \mathrm{y}$. Due to low recovery (1.4 $\mathrm{m}$ out of $9 \mathrm{~m}$ cored), the lowermost 7.5 meters of sediment was possibly not sampled. Taking into account the Paleocene sedimentation rate ( $\sim 9 \mathrm{~m} / \mathrm{m} . \mathrm{y}$.), this places the above age in error by not more than about $1 \mathrm{~m} . \mathrm{y}$. and gives for the oldest sediment a possible age of 62 to 64 m.y. Site 245 is located on the older side (south) of anomaly 29 , which has been clearly identified in the Madagascar Basin on profiles MD1-21 and C11 (both run in a northeastsouthwest direction on either side of Site 245.) The magnetic age of the crust at this site is therefore 69.5 m.y. old, according to the Heirtzler et al. (1968) time scale, which is 6.5 to 8.5 million years older than the age of the oldest sediment recovered, or 5.5 to 7.5 million years if the unrecovered 7.5 meters of sediment are taken into account.

The correspondence of the biostratigraphic (Casey, 1964) and magnetic time scale can be considered as well established at Site 239 for Late Cretaceous time. At Site 245, the difference of about $7 \mathrm{~m} . \mathrm{y}$. between the biostratigraphic time scale (Berggren, 1972) and the Heirtzler et al. (1968) magnetic time scale is somewhat doubtful since the basal sediments were not recovered and since the recovered basaltic basement is of intrusive origin, which leaves open the possibility of coring older sediments deeper in the hole. Moreover, if there is an unconformity similar to that found at Site 239 (7 to 11 m.y. between Late Cretaceous and early Paleocene), there might be no discrepancy at all in the age of the oldest sediment and the magnetic anomaly. Sclater et al. (in press) considered all DSDP sites drilled before or during Leg 22 which are located on, or close to, identifiable magnetic anomalies and for which a good age determination for the basal sediments is available. From eight of these sites $(14,15,16,19,20$, 32,39 , and 213) the authors proposed an adjustment of the Heirtzler et al. (1968) time scale which yields for anomaly 31 (older side) an age of $67 \mathrm{~m} . \mathrm{y}$. and for anomaly 29 (older side) an age of 64.7 m.y. The 67 m.y. magnetic age derived from this adjusted scale for anomaly 31 (older side) observed at Site 239 does not fit with the biostratigraphic age of $72 \mathrm{~m} . \mathrm{y}$. However, the $64.7 \mathrm{~m} . \mathrm{y}$. magnetic age for anomaly 29 (older side) observed at Site 245 is in fairly good agreement with the possible real basement age of $>62$ to $64 \mathrm{~m} . \mathrm{y}$. It is clear that before deriving any new time scale for magnetic field reversals, complementary drilling data on identified magnetic anomalies are required. Nevertheless, it can be suggested, at least as a guideline, that the Heirtzler et al. (1968) Paleogene time scale should be adjusted and made younger by a factor of about $7 \%$ (Schlich, 1973; Sclater et al., in press) but that for Late Cretaceous time, the present time scale (Heirtzler et al., 1968), complemented beyond anomaly 30 by McKenzie and Sclater (1971) still can be used.

\section{ACKNOWLEDGMENTS}

I would like to thank Captain M. Bilhaut, and the officers and crew of Gallieni (1967-1972) and Marion
Dufresne (1973) for their continuous help while collecting the geophysical data presented here. I wish also to thank the Global Marine shipboard staff, in particular, Captain J. Clarke and Operations Manager J. Shore for the success of Leg 25 Cruise. I would like to express my gratitude to all technicians and engineers who contributed to the collection of data at sea and to the later processing on shore, especially to Michele Bitterly for our sophisticated marine geophysical data reduction programs. Discussions with my colleague Philippe Patriat, who made many significant contributions to this paper, were most useful.

I am also greatly indebted to Terres Australes et Antarctiques Francaises who provided most of the ship time (Gallieni and since 1973, Marion Dufresne) involved in the research program. This work was supported by Institut de Physique du Globe de Paris (University de Paris VI), Centre National de la Recherche Scientifique (RCP 212) Institut, National d'Astronomie et de Géophysique (opération "Océan Indien"), Centre National pour l'Exploitation des Océans, and the National Science Foundation.

\section{REFERENCES}

Berggren, W. H., 1972. A Cenozoic time scale-some implications for regional geology and paleobiogeography: Lethaia, v. 5, p. 195-215.

Bergh, H., 1971. Sea floor spreading in the southwest Indian Ocean: J. Geophys. Res., v. 76, p. 6276.

Cain, J. C., Hendricks, S., Daniels, W. E., and Jensen, D. C., 1964. Computation of the main geomagnetic field from spherical expansion: NASA X611-64-316.

Cann, J. R. and Vine, F. J., 1966. An area on the crest of the Carlsberg Ridge: petrology and magnetic survey: Roy. Soc. London, Phil. Trans., v. 259, p. 198-217.

Casey, R., 1964. The Cretaceous period. In Harland, W. B., Smith, A. G., and Wilcock, B., The Phanerozoic time scale: Geol. Soc. London Quart. J., Suppl. 1, p. 193-202.

Fisher, R. L., Johnson, G. L., and Heezen, B. C., 1967. Mascarene Plateau, western Indian Ocean: Geol. Soc. Am. Bull., v. 78, p. 1247-1266.

Fisher, R. L., Engel, C. G., and Hilde, T. W. C., 1968. Basalts dredged from the Amirante Ridge, western Indian Ocean: Deep-sea Res., v. 15, p. 521-534.

Fisher, R. L., Sclater, J. G., and McKenzie, D. P., 1971. Evolution of the Central Indian Ridge, western Indian Ocean: Geol. Soc. Am. Bull., v. 82, p. 553-562.

Francis, T. J. G. and Raitt, R. W., 1967. Seismic refraction measurements in the southern Indian Ocean: J. Geophys. Res., v. 72, p. 3015-3042.

Heezen, B. C. and Tharp, M., 1965. Physiographic diagram of the Indian Ocean (with descriptive sheet): New York (Geol. Soc. Am.)

Heirtzler, J. R., Dickson, G. O., Herron, E. M., Pitman, W. C., and Le Pichon, X., 1968. Marine magnetic anomalies, geomagnetic field reversals, and motions of the ocean floor and continents: J. Geophys. Res., v. 73, p. 2119-2136.

Langseth, M. G. and Taylor, P. T., 1967. Recent heat flow measurements in the Indian Ocean: J. Geophys. Res., v. 72 , p. $6249-6260$.

Laughton, A. S., Matthews, D. H., and Fisher, R. L., 1970. The structure of the Indian Ocean. In Maxwell, A. E. (Ed.), The Sea: v. 4, p. 543-586.

Le Pichon, X. and Heirtzler, J. R., 1968. Magnetic anomalies in the Indian Ocean and sea floor spreading: J. Geophys. Res., v. 73, p. 2101-2117. 
Matthews, D. H., 1966. The Owen fracture zone and the northern end of the Carlsberg Ridge: Roy. Soc. London Phil. Trans., v. 259, p. 172-186.

McKenzie, D. P. and Sclater, J. G., 1971. The evolution of the Indian Ocean since the Late Cretaceous: Roy. Astron. Soc. Geophys. J., v. 25, p. 437-528.

Pitman, W. C., and Heirtzler, J. R., 1966. Magnetic anomalies over the Pacific-Antarctic Ridge: Science, v. 154. p. 1164-1171.

Schlich, R., 1973. Quand les géophysiciens explorent l'Océan Indien: La Recherche no. 40, p. 1100-1104.

Schlich, R. and Patriat, P., 1967. Profils magnétiques sur la dorsale médio-océanique "Indo-Pacifique:" Ann. de Geophysique, v. 23, p. 629-633.

1971a. Anomalies magnétiques de la branche Est de la dorsale médio-indienne entre les iles Amsterdam et Kerguelen: Compt. Rendus Acad. Sci. Paris, v. 272, p. 773-776.

1971b. Mise en évidence d'anomalies magnétiques axiales sur la branche ouest de la dorsale médio-indienne: Compt. Rendus Acad. Sci. Paris, v. 272, p. $700-703$.

1971c. Expansion des fonds océaniques dans l'Océan Indien Austral: Communication présentée à la XV: Assemblée Générale de l'UGGI, Moscow.

Schlich, R., Delteil, J. R., Moulin, J., Patriat, P., and Guillaume, R., 1971. Mise en évidence d'une sédimentation de marge continentale sur le plateau de Kerguelen-Heard: Compt. Rendus Acad. Sci. Paris, v. 272, p. $2060-2063$.

Schlich, R., Patriat, P., and Ségoufin, J., 1972. Compterendu d'activité pour la periode du ler Avril 1971 au 29 Février 1972: Note IPG de Paris, $\mathrm{N}^{\circ} 46$.

Sclater, J. G. and Fisher, R. L., in press. The evolution of the east central Indian Ocean with emphasis on the tectonic setting of the Ninetyeast Ridge: Geol. Soc. Am. Bull.
Sclater, J. G., and Francheteau, J., 1970. The implications of terrestrial heat flow observations on current tectonic and geochemical models of the crust and upper mantle of the earth: Roy. Astron. Soc. Geophys. J., v. 20, p. 509-542.

Sclater, J. G., Anderson, R. N., and Lee Bell, M., 1971a. Elevation of ridges and evolution of the central eastern Pacific: J. Geophys. Res., v. 76, p. 7888-7915.

Sclater, J. G., Jarrard, R. D., and Gartner, S., in press. Comparison of the magnetic and biostratigraphic time scales since the Late Cretaceous. In von der Borch, C, Sclater, J. G., et al., Initial Reports of the Deep Sea Drilling Project, Volume 22: Washington (U.S. Government Printing Office.)

Sclater, J. G., Ritter, V., Hilton, W., Meinke, L. and Fischer, R. L., 1971b. Charts of residual magnetic field plotted along track for the Indian Ocean: Scripps Institution of Oceanography, Special Rept., $\mathrm{N}^{\circ} 71-77$.

Sclater, J. G., von der Borch, C., Veevers, J. J., Hekinian, R., Thompson, R. W., Pimm, A. C., McGowran, B., Gartner, S., and Johnson, D. A., in press. Regional synthesis of the Deep Sea Drilling results from Leg 22 in the eastern Indian Ocean. In Initial Reports of the Deep Sea Drilling Project, Volume 22: Washington (U.S. Government Printing Office.)

Udintsev, G. B., 1965. New data on the bottom topography of the Indian Ocean: Okeanologiya, v.5, p. 993-998.

Vine, F. J., 1966. Spreading of the ocean floor: new evidence: Science, V. 154, p. 1405-1415.

Vine, F. J. and Matthews, D. H., 1963. Magnetic anomalies over oceanic ridges: Nature, v. 199. p. 947-949.

Zhivago, A. V., 1967. Bottom morphology and tectonics of the Southern Ocean: Proc. Symposium Pacific-Antarctic Sci., Japan. Antarct. Res. Exp., Sci. Rep., Spec. Issue 1, p. 124-135. 